\title{
Analisa Kinerja Pompa Kalor Termoakustik Pada Frekuensi Harmonik Orde 1, 3, 5 dan 7 Menggunakan Stack Berpori Lingkaran
}

\author{
Agus Cahyono, Wahyu Nur Achmadin, Ikhsan Setiawan and Agung Bambang Setio Utomo*
}

\begin{abstract}
Ringkasan
Telah dilakukan penelitian tentang kinerja pompa kalor termoakustik, meliputi laju pemanasan dan pendinginan, menggunakan tabung resonator dengan panjang $70 \mathrm{~cm}$ dan diameter $4,6 \mathrm{~cm}$ pada frekuensi harmonik orde 1 , 3, 5 dan 7. Stack yang digunakan dari bahan plastik dengan panjang $10 \mathrm{~cm}$ dan pori-pori bentuk lingkaran berdiameter tertentu. Hasil penelitian menunjukkan bahwa perbandingan beda suhu optimum antara bagian panas dan dingin untuk frekuensi harmonik orde pertama, ketiga, kelima dan ketujuh adalah 27:9:3:1.
\end{abstract}

Kata Kunci : Stack, pori lingkaran, frekuensi harmonic, beda suhu

\section{Abstract}

The experiment to know the thermoacoustic heat pump performance, which is included of warming and cooling rates, has been done using a resonator pipe with the length of $70 \mathrm{~cm}$ and diameter of $4,6 \mathrm{~cm}$ on the $1^{\text {st }}$, $3^{\text {rd }}, 5^{\text {th }}$ and $7^{\text {th }}$ orde of harmonic frequencies. The stack material consists of plastic with the length of $10 \mathrm{~cm}$ and a certain circle pored diameter. The result of this experiment is obtained that the ratio of the optimum temperature difference from hot and cool part for harmonic frequencies on the $1^{\text {st }}, 3^{\text {rd }}, 5^{\text {th }}$ and $7^{\text {th }}$ orde are 27:9:3:1 respectively.

Keywords: stack; circle pore; harmonic frequency; temperature difference

\section{PENDAHULUAN}

Seiring dengan ditemukannya berbagai teknologi canggih dan modern serta diiringi tingkat kehidupan manusia yang semakin maju membuat segala sesuatunya serba kompleks tapi kadang berdampak. Dalam hal ini misalnya saja adanya penggunaan peralatan pendingin AC atau lemari Es yang menggunakan gas tertentu akan tetapi berdampak pada kesehatan walaupun dalam jangka lama. Karena alasan itulah perlu diciptakan teknologi modern yang sederhana, murah, praktis tetapi tidak berdampak buruk terhadap kehidupan manusia dan lingkungan. Untuk dapat mewujudkan itu semua, penelitian perlu dilakukan guna menunjang keberhasilan terciptanya teknologi yang ramah lingkungan tersebut.

Salah satu penelitian tentang sistem pendingin yang ramah lingkungan adalah sistem termoakustik

\footnotetext{
*Correspondence: agungbambang@ugm.ac.id

Jurusan Fisika, Fakultas Matematika dan Ilmu Pengetahuan Alam,

Universitas Gadjah Mada, Yogyakarta, Indonesia

Full list of author information is available at the end of the article

${ }^{\dagger}$ Equal contributor
}

dengan udara sebagai mediumnya. Diharapkan dalam penelitian ini dapat dipelajari fenomena yang terjadi pada peranti termoakustik dan ke depannya dapat menjadikan teknologi termoakustik sebagai salah satu teknologi yang dapat diandalkan.

Termoakustik adalah suatu bidang yang berkaitan dengan fenomena fisis di mana perbedaan suhu dapat membangkitkan gelombang akustik (bunyi) atau sebaliknya gelombang bunyi dapat menimbulkan perbedaan suhu. Secara umum peranti termoakustik dikelompokkan menjadi dua jenis, yaitu yang menghasilkan gelombang bunyi akibat adanya perbedaan suhu disebut mesin kalor termoakustik. Sedangkan alat yang menghasilkan perbedaan suhu akibat gelombang bunyi disebut pendingin termoakustik. Teknologi termoakustik menawarkan keuntungan besar bila ditinjau dari aspek ekonomis serta dampak aplikasinya bagi kehidupan [1].

Adapun beberapa aplikasi dari teknologi ini, antara lain adalah pendingin keping elektronik (chip), suhu tinggi bisa digunakan untuk mencairkan gas alam dan 
sebagai pendingin perlengkapan elektronik pada kapal laut [2].

Dengan adanya beberapa keuntungan yang bisa didapatkan dari teknologi ini, maka tidaklah mengherankan bila penelitian mengenai teknologi ini banyak dilakukan oleh para ilmuwan. Hal ini berkaitan dengan masih banyaknya parameter kinerja sistem pompa termoakustik agar kinerjanya optimum. Oleh karena itulah penelitian yang berkelanjutan mengenai teknologi ini perlu dilakukan.

Penelitian akan dibatasi pada pengaruh stack diameter pori lingkaran dari bahan plastik terhadap kinerja pompa kalor termoakustik kemudian dengan menggunakan stack optimum ini dapatlah dikaji kinerja pompa kalor termoakustik saat beroperasi pada frekuensi harmonik orde 1, 3, 5 dan 7 . Dalam penelitian ini diameter pori stack yang digunakan ada 4 jenis, (jenis 1 berdiameter $2,13 \mathrm{~mm}$, jenis 2 berdiameter $2,45 \mathrm{~mm}$, jenis 3 berdiameter $3,61 \mathrm{~mm}$ dan jenis 4 berdiameter 4,93 mm). Optimasi diameter stack ditunjukkan dengan indikator perbandingan beda suhu (antara suhu panas dan dingin) yang dihasilkan pompa kalor termoakustik.

Banyak artikel tentang termoakustik yang dimuat dalam berbagai jurnal ilmiah diantaranya yang dipelopori oleh Wheatley dkk (1985) [3] yang menuliskan tentang pemahaman dasar fenomena termoakustik. Penelitian berlanjut pada tahun 1988 oleh Swift [4] yang menyatakan bahwa bentuk resonator silindris merupakan bentuk resonator termudah untuk peranti termoakustik. Swift (1995) [5] menuliskan tentang teori dasar dan aplikasi termoakustik.

Penelitian tentang teknologi termoakustik terus berlanjut, Russel dan Weibull (2002) [6] mampu membuat sebuah peranti termoakustik untuk demonstrasi yang menghasilkan perbedaan suhu sekitar $15^{\circ} \mathrm{C}$ dalam waktu 4 menit pengoperasian. Swift (2002) [7] meneliti tentang jarak antar lapisan stack dan diperoleh hasil bahwa penurunan suhu maksimum didapat ketika jarak antar lapisan/dinding stack tertentu. Tijani dkk (2002) [8] melakukan penelitian termoakustik dengan menggunakan stack berbahan sedotan (plastik) minuman yang menghasilkan beda suhu $30^{\circ} \mathrm{C}$ untuk diameter pori-pori stack $2 \mathrm{~mm}$. Demonstrasi eksperimental tentang konversi energi termoakustik dalam sebuah resonator juga telah dilakukan oleh Biwa dkk (2004) [9].

Saat ini penelitian termoakustik sedang dilakukan di Laboratorium Fisika Atom dan Inti FMIPA UGM. Dimulai tahun 2005 penelitian tentang termoakustik telah berhasil merancang dan membuat sebuah peranti termoakustik sebagai sarana pendingin dan pemanas secara simultan [10, 11]. Uji kinerja alat ini dengan memvariasikan frekuensi dan amplitudo gelombang bunyi yang digunakan dan diperoleh bahwa pada frekuensi $152 \mathrm{~Hz}$ dan tegangan speaker 11 volt didapat perbedaan suhu $13^{\circ} \mathrm{C}$ (stack dari bahan kardus) dan beda suhu sebesar $12,5^{\circ} \mathrm{C}$ (stack dari bahan film). Elyanita (2006) [12] melakukan penelitian mengenai pengaruh variasi frekuensi dan posisi stack bahan kardus terhadap perubahan suhu pada sistem termoakustik dan diperoleh bahwa posisi terbaik stack dengan beda suhu optimal yang didapat sebesar $9^{\circ}$ $\mathrm{C}$ adalah pada frekuensi $150 \mathrm{~Hz}$. Penelitian mengenai pengaruh diameter resonator terhadap kinerja peranti termoakustik dilakukan oleh Sampurna (2006) [13], didapatkan bahwa diameter optimum adalah 4,6 $\mathrm{cm}$ dengan beda suhu sebesar $10,9^{\circ} \mathrm{C}$ dalam waktu 10 menit pengoperasian. Wagiyanti (2007) [14] berhasil melakukan penelitian mengenai korelasi panjang resonator $70 \mathrm{~cm}$ diameter $3,8 \mathrm{~cm}$ dengan stack dari bahan kertas manila dengan panjang stack $10 \mathrm{~cm}$ di dapat beda suhu $23^{\circ} \mathrm{C}$.

\section{Tinjauan teori}

Gelombang bunyi dapat terjadi karena adanya perapatan dan perenggangan molekul-molekul medium (padat, cair atau gas) yang dilaluinya. Gelombang bunyi dibatasi oleh jangkauan frekuensi yang dapat merangsang telinga dan otak manusia melalui sensasi pendengaran $(20 \mathrm{~Hz}$ sampai dengan $20.000 \mathrm{~Hz})[15]$.

Terkait dengan penelitian termoakustik, satu hal yang menjadi komponen penting adalah gelombang bunyi. Gelombang bunyi yang ditimbulkan oleh sumber harmonik disebut gelombang bunyi harmonik, misalnya saja garpu tala dan speaker yang dihubungkan dengan sistem pembangkit gelombang.

Simpangan gelombang sebagai fungsi posisi $x$ dan waktu $t$ bagi gelombang bunyi harmonik akan menyebabkan terjadinya perubahan kerapatan dan tekanan udara. Oleh karena tekanan dalam gas sebanding dengan kerapatan, maka perubahan tekanan akan maksimum ketika perubahan kerapatannya maksimum. Ketika gelombang bunyi bergerak seiring waktu, simpangan molekul udara, kerapatan dan tekanan pada satu titik semuanya berubah secara sinusoidal dengan frekuensi $f$ yang sama dengan frekuensi sumbernya.

Pada Gambar 1, (a) menunjukkan simpangan dan titik setimbang molekul-molekul udara dalam gelombang bunyi harmonik versus posisi. Posisi kesetimbangan pada $x_{1}$ dan $x_{3}$ sedangkan simpangan maksimum di $x_{2}$. (b) Beberapa molekul ditempatkan pada posisi kesetimbangannya sebelum gelombang bunyi tiba. Arah anak panah menyatakan arah 


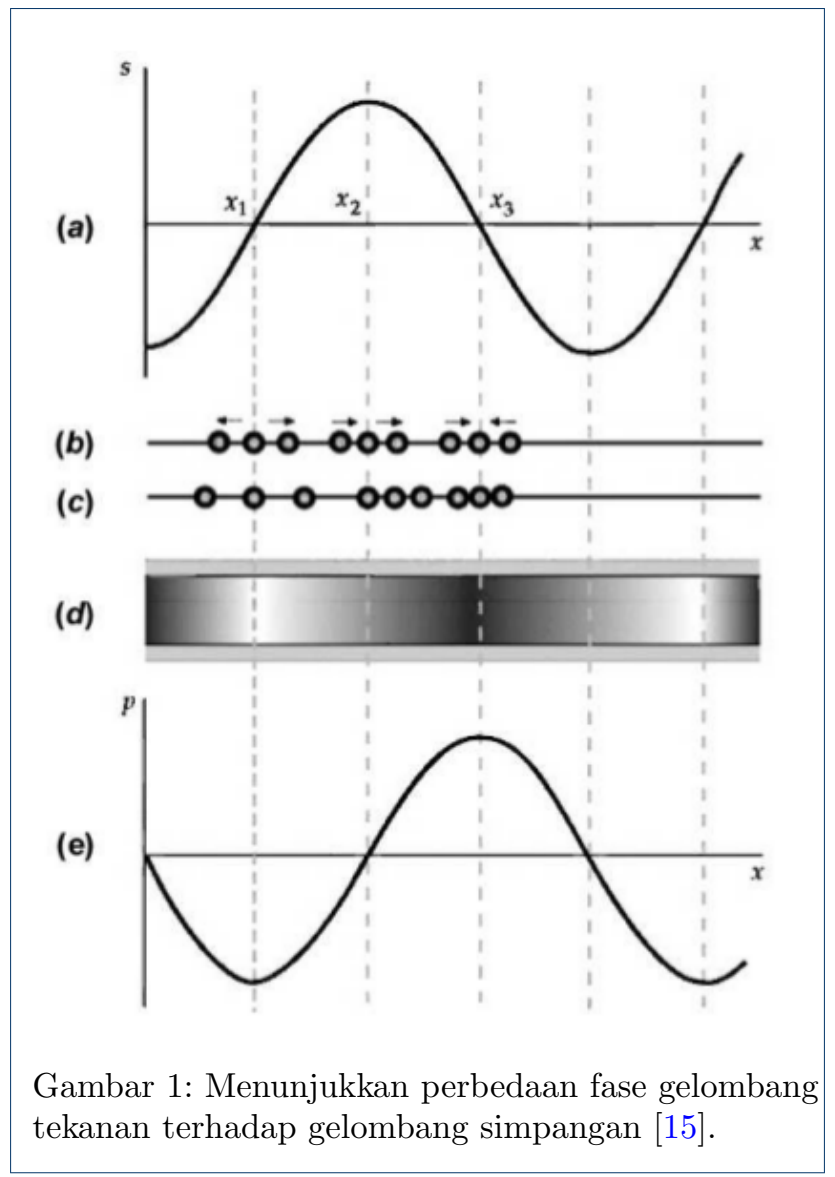

simpangan yang disebabkan oleh gelombang bunyi. (c) Molekul-molekul di dekat $x 1, x_{2}$, dan $x_{3}$ setelah gelombang bunyi tiba. (d) Kerapatan maksimum pada $x_{3}$ dan minimum pada $x_{1}$. (e) Perubahan tekanan versus posisi. Perubahan tekanan dan simpangan berbeda fase $90^{\circ}$ [15].

Ditinjau sebuah pipa semi tertutup (satu ujung tertutup dan ujung lainnya berbuka). Dalam hal ini selalu dicirikan dengan adanya simpul simpangan di ujung pipa tertutup sedangkan ujung terbuka berwujud perut simpangan. Panjang gelombang simpangan molekul udara di dalam pipa adalah panjang gelombang yang sesuai dengan panjang pipa sehingga terdapat simpul pada ujung tertutupnya. Hal ini dapat dilihat dari persamaan yang mewakili sistem pipa semi tertutup, sebagai

$$
L=\frac{2 n-1}{4} \lambda_{n} ; n=1,2,3, \ldots
$$

dengan $L$ adalah panjang pipa, $\lambda_{n}$ adalah panjang gelombang bunyi dan $n$ adalah bilangan bulat yang sering disebut sebagai ragam getaran. Bila $n=$ 1 maka yang terjadi adalah nada dasar (harmonik pertama), sedangkan $n=2$ berarti nada atas pertama (harmonik kedua) dan seterusnya. Pada pipa organa semi tertutup frekuensi dasarnya adalah $v / 4 L$, dengan $v$ adalah cepat rambat gelombang bunyi di udara, sehingga harmonik yang ada hanya harmonik angka ganjil.

Terlihat pada pipa silindris semi tertutup (Gambar 2), pada ujung tertutup terjadi simpul simpangan dan perut simpangan pada ujung terbuka dengan modus dasar getaran adalah $\lambda=4 L$ dan modus berikutnya adalah $3 \lambda=4 L$ atau secara umum syarat frekuensi gelombang berdiri dapat dituliskan sebagai

$$
f_{n}=(2 n-1) \frac{v}{4 L} ; n=1,2,3, \ldots
$$

dengan frekuensi alami sistem ini terjadi dalam rasio $1: 3: 5: 7 \ldots$, yang berarti bahwa harmonik genap hilang.

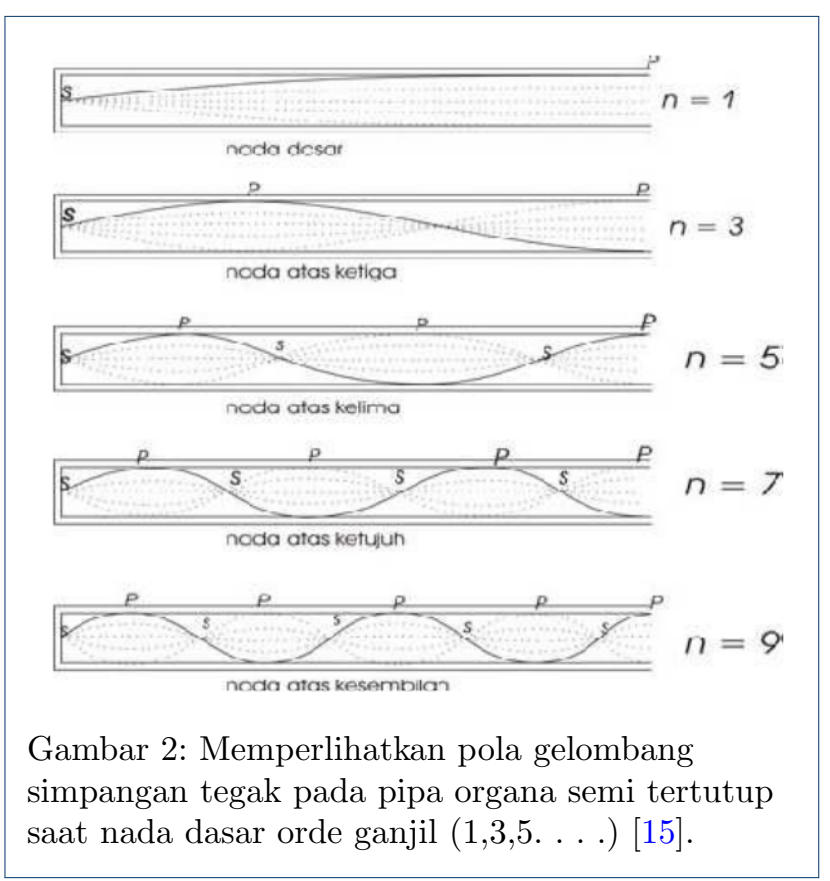

Di lain pihak kajian termodinamika mencakup pengetahuan dasar tentang suhu, kalor, dan sifat-sifat yang dipengaruhi oleh suhu dan kalor. Dalam termodinamika dikenal sebagai Hukum Pertama Termodinamika, yang intinya mengatakan bahwa energi bersifat kekal. Kerja $d W$ mencakup semua jenis kerja mekanik, elektrik, dan magnetik. Apabila sejumlah gas berada dalam sebuah bejana silinder berpiston diberi kalor sebesar $d Q$ pada tekanan tetap maka sebagian kalor digunakan untuk menaikkan suhu gas atau tenaga internal sistem sebesar $d U$ dan sebagian lagi digunakan untuk melakukan kerja luar (oleh sistem) sebesar $d W$, yang secara umum 
dituliskan sebagai

$$
d Q=d U+d W
$$

Pada sebuah skema kerja sistem (Gambar 3), dengan $T_{P}$ (suhu tandon panas) dan $T_{D}$ (suhu tandon dingin), $Q_{P}$ adalah kalor dari tandon panas dan $Q_{D}$ adalah kalor menuju tandon dingin akan diperoleh $W$ usaha mekanik sebesar $W$. Di lain pihak

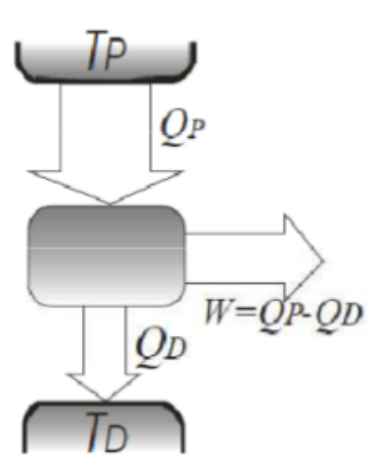

Gambar 3: Hasil kerja $W$ dari kalor $Q_{P}$ yang diserap dari tandon suhu tinggi $T_{P}$ dan membuang kalor $Q_{D}$ ke tandon yang bersuhu rendah $T_{D}$.

mekanisme kerja sistem termoakustik didasarkan pada operasi sistem pendingin atau pompa kalor. Gambar 4, memperlihatkan operasi dasar sebuah sistem pendingin atau pompa kalor, di mana suatu kerja dari luar $W$, misalnya gelombang bunyi, memindahkan sejumlah kalor $Q$ dari tandon (reservoir) suhu rendah $T_{D}$ ke tandon suhu tinggi $T_{P}$.

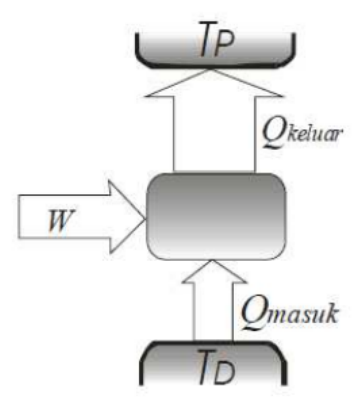

Gambar 4: Operasi dasar sebuah pendingin atau pompa kalor, dengan kerja $W$ dari luar memindahkan kalor $Q$ dari tandon (reservoir) suhu rendah $T_{D}$ ke tandon suhu tinggi $T_{P}$.

Jika siklus tersebut berulang maka akan terjadi pengurangan kalor pada tandon bersuhu $T_{D}$ dan menambah kalor pada tandon bersuhu $T_{P}$. Hal ini berakibat akan semakin turunnya suhu pada tandon $T_{D}$ dan sebaliknya akan meningkatkan suhu pada tandon $T_{P}$.

Siklus proses pendinginan secara termoakustik dapat dilihat pada Gambar 5. Saat gelombang bunyi menyebabkan paket gas di dalam stack bergerak ke bagian kiri (panas), maka tekanan akan meningkat dan gas termampatkan. Paket gas yang termampatkan ini sekarang lebih panas dari dinding stack di dekatnya sehingga gas akan melepaskan kalor ke stack sehingga menyusutkan volume paket gas tersebut. Saat gelombang berdiri melanjutkan siklusnya, paket gas ditarik kembali ke bagian yang tekanannya lebih rendah (kanan), paket gas menjadi lebih renggang dan lebih dingin dari pada dinding di sekitarnya, sehingga gas menyerap kalor dari dinding stack untuk mengembang. Siklus ini terus berulang dan efeknya adalah transfer kalor dari bagian dingin (kanan) ke bagian panas (kiri) stack.

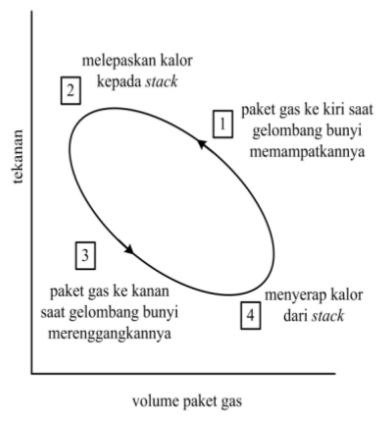

(a)

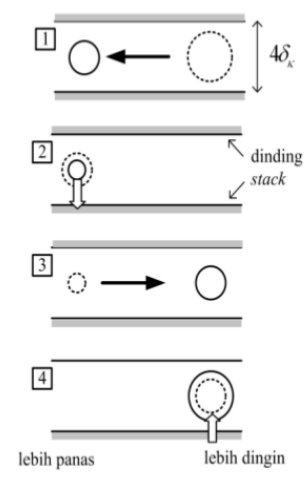

(b)
Gambar 5: (a) Diagram P -V yang memperlihatkan empat tahap dalam siklus pendingin (refrigerator) termoakustik, (b) proses transfer kalor antara paket gas dan dinding stack [6].

\section{Results And Discussion}

\section{Alat yang digunakan}

Skema susunan peralatan termoakustik secara lengkap (Gambar 6) dengan komponen/peralatan, yaitu sistem sumber bunyi (terdiri dari Loudspeaker + kotaknya dari Woofer, ACR, model C $610 \mathrm{WH}$, max power 60 watts, impedansi 8 ohm, Digital Audio Function Generator model GFG-8016 G, Power Amplifier, Karaoke AV Sistem, MV 8000 MEGAFOX dan Multimeter SANWA), sistem Deteksi Suhu (terdiri dari dua buah termometer batang) dan sistem Deteksi 
Bunyi (terdiri dari MIC Kondensor + Pre-Amp + Kabel dan Komputer + sound card + perangkat lunak Winscope 2.51).

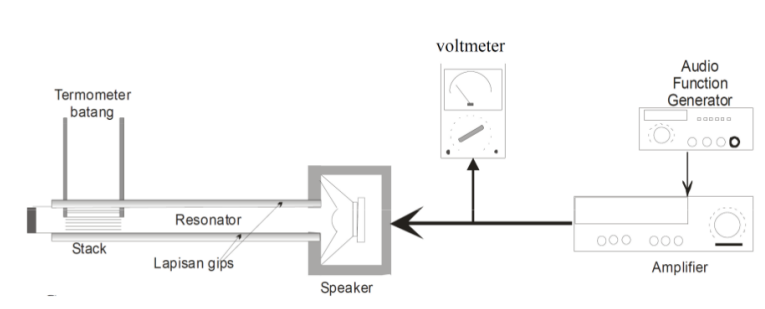

Gambar 6: Skema peralatan yang digunakan dalam penelitian termoakustik, dengan dua buah termometer sebagai pendeteksi suhu, ketika mencari beda suhu terbaik untuk 4 jenis diameter stack yang berbeda [16].

\section{Bahan Penelitian}

Bahan yang digunakan dalam penelitian ini berupa Tabung Resonator (terbuat dari pipa PVC berdiameter $4,6 \mathrm{~cm}$ dengan panjang $70 \mathrm{~cm}$ ), Stack yang terbuat dari bahan plastik berdiameter $2,13 \pm 0,05 \mathrm{~mm}$ (isi ballpoint); 2, 45 $\pm 0,05 \mathrm{~mm}$ (pembungkus kabel); 3,61 $\pm 0,05 \mathrm{~mm}$ (sedotan minuman air mineral kemasan gelas), dan 4, 93 $\pm 0,05$ mm (sedotan minuman).

Setelah frekuensi resonansi diperoleh $f=120 \mathrm{~Hz}$ pada $n=1$ menggunakan winscope, ditunjukkan pada puncak sinyal keluaran tertinggi, maka dapat pula diperoleh optimasi diameter pori-pori stack bahan plastik panjang $10 \mathrm{~cm}$ dengan variasi empat jenis diameter pori yang berbeda $(2,13 \mathrm{~mm} ; 2,45 \mathrm{~mm} ; 3,61$ $\mathrm{mm}$ dan $4,91 \mathrm{~mm}$ ) dengan tegangan input speaker maksimal 15 volt. Pada tiap variasi pori bahan stack, laju pendinginan dan pemanasan (perubahan suhu antara bagian panas dan dingin) diamati dan dicatat tiap 1 menit dalam waktu 10 menit. Perbedaan suhu terbesar setelah 10 menit pengamatan dari tiap variasi diameter pori-pori stack menunjukkan diameter optimal.

\section{Menyelidiki karakteristik dari mic pendeteksi bunyi.}

Hal pertama yang dilakukan untuk mengetahui kemampuan mic dalam mendeteksi bunyi adalah dengan mencari sinyal keluaran optimal untuk berbagai posisi mic saat dioperasikan pada frekuensi harmonik 1, 3, 5 dan 7. Dalam hal ini mic dipasang mulai dari ujung dekat sumber bunyi kemudian digeser tiap $5 \mathrm{~cm}$ sampai ujung tertutup dengan tegangan input speaker maksimal untuk masing-masing frekuensi. Pengamatan sinyal keluaran dilakukan dengan winscope dan multimeter. Setelah didapatkan posisi tertentu di mana sinyal keluaran dari mic paling optimal, input speaker diturunkan hingga minimum namun sinyal keluaran mic masih bisa dideteksi. Selanjutnya input speaker dinaikkan tiap 1 volt dan dilakukan pengamatan sinyal keluaran mic untuk tiap kenaikan.

\section{Menyelidiki pengaruh frekuensi harmonic orde 1, 3, 5 dan 7 terhadap bentuk gelombang yang terjadi pada resonator}

Untuk mengetahui bentuk gelombang di dalam resonator, dilakukan dengan cara menggeser mic dari ujung sumber sampai ujung tertutup untuk tiap $5 \mathrm{~cm}$ (Gambar 7). Pengamatan bentuk gelombang dilakukan dengan memasang pendeteksi bunyi (mic) pada resonator untuk berbagai variasi posisi pada frekuensi AFG $f_{A} F G=120 \mathrm{~Hz}$ (frekuensi resonansi) yang menunjukkan nada dasar pertama, begitu selanjutnya. Dari berbagai posisi mic yang dipasang, diamati sinyal keluaran pada winscope (a.u) dengan posisi mic dimulai dari ujung dekat sumber bunyi dan kemudian mic digeser tiap $5 \mathrm{~cm}$ sampai mendekati ujung tertutup. Dari masing-masing sinyal keluaran kemudian di plot dalam grafik yang menunjukkan bentuk gelombang tekanan pada resonator, sehingga dapat diselidiki bentuk gelombang yang terjadi pada frekuensi harmonik orde pertama, ketiga, kelima dan ketujuh.

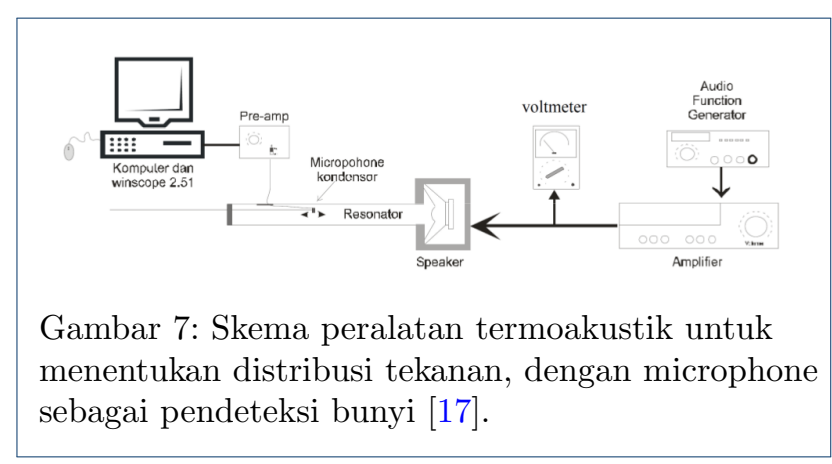

\section{Menyelidiki perbedaan suhu yang dihasilkan untuk berbagai posisi stack saat beroperasi pada frekuensi harmonik orde pertama, ketiga, kelima dan ketujuh.}

Pada tahap ini stack yang digunakan adalah stack dengan diameter pori-pori optimal dengan panjang stack tetap $10 \mathrm{~cm}$ [16]. Penelitian pertama dilakukan pada frekuensi harmonik orde pertama dengan posisi 
stack divariasi dari posisi $15 \mathrm{~cm}$ sampai $60 \mathrm{~cm}$ dari ujung sumber dan diamati perubahan suhu tiap menit sehingga dapat dihitung perbedaan suhu setelah 10 menit pengamatan (Gambar 8). Hal yang sama dilakukan untuk frekuensi harmonik orde ketiga, kelima dan ketujuh serta dibandingkan besarnya perbedaan suhu yang dihasilkan antara bagian panas dan dingin untuk frekuensi harmonik orde pertama, ketiga, kelima dan ketujuh.

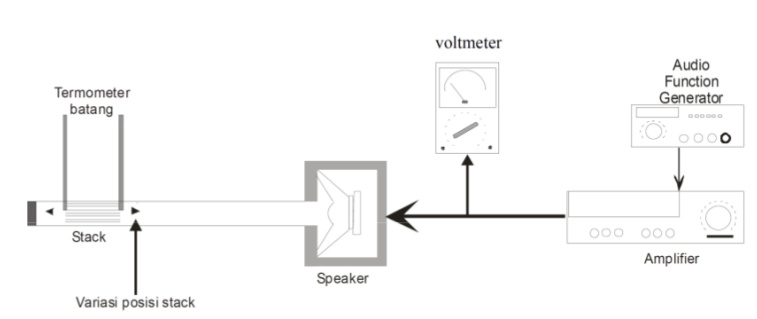

Gambar 8: Skema peralatan optimalisasi posisi stack dan perbandingan beda suhu optimum pada frekuensi harmonik orde 1, 3, 5 dan 7. [17]

\section{HASIL DAN PEMBAHASAN}

Menggunakan tegangan masukan speaker maksimal sebesar 15 volt, gelombang sinyal keluaran dan spektrum bunyi dari sumber bunyi dapat diketahui melalui scope dan mengaktifkan mikrofon dengan mengubah frekuensi masukan.

\section{Karakteristik MicPendeteksi Bunyi.}

Pada Gambar 9, ditunjukkan sinyal keluaran mictertinggi pada posisi $55 \mathrm{~cm}$ dari ujung terbuka untuk frekuensi harmonik 1, 3 dan 7, sedang untuk harmonik 5 pada posisi $50 \mathrm{~cm}$ dari ujung terbuka.

Dari posisi ini ketika tegangan diturunkan sampai minimum yaitu 2 volt, sinyal yang teramati pada scope mengalami penurunan. Setelah tegangan kita naikkan tiap satu volt, ternyata untuk tiap-tiap frekuensi akan mengalami titik jenuh (datar) pada tegangan tertentu. Untuk frekuensi $120 \mathrm{~Hz}$ dan $360 \mathrm{~Hz}$ titik datar terjadi pada 5 volt, pada frekuensi $600 \mathrm{~Hz}$ terjadi pada 4 volt dan pada frekuensi $840 \mathrm{~Hz}$ terjadi pada 3 volt .

\section{Bentuk gelombang dalam resonator pada frekuensi harmonic orde $1,3,5$, dan 7.}

Sebelum meninjau data beda suhu tiap frekuensi harmonik, terlebih dahulu dilihat bentuk gelombang dari masing masing frekuensi harmonik. Tabung resonator yang digunakan, termasuk sumbat karet pada ujungnya, sebagai medium perambatan

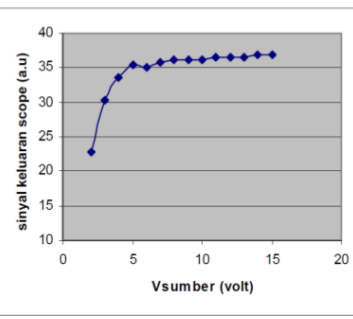

(a)

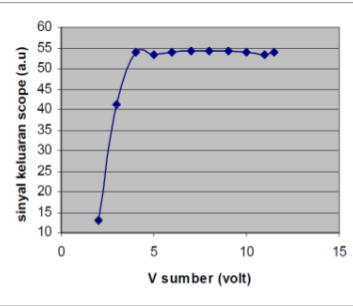

(c)

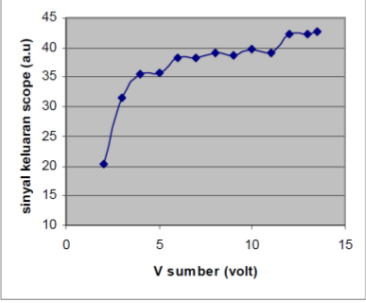

(b)

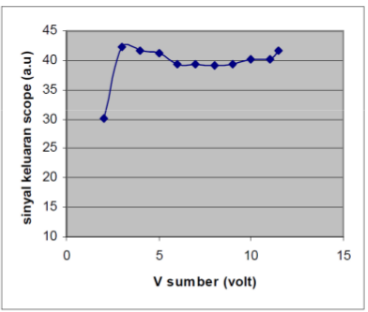

(d)
Gambar 9: Grafik V sumber vs sinyal keluaran pada scope saat frekuensi (a) $120 \mathrm{~Hz}$, (b) $360 \mathrm{~Hz}$, (c) $600 \mathrm{~Hz}$, (d) $840 \mathrm{~Hz}$. [17]

gelombang bunyi panjangnya $70 \mathrm{~cm}$. Dimulai pada frekuensi harmonik pertama sebesar $120 \mathrm{~Hz}$ (frekuensi resonansi) dan selanjutnya frekuensi harmonik ketiga $(f=360 \mathrm{~Hz})$, kelima $(f=600 \mathrm{~Hz})$ dan ketujuh $(f=840 \mathrm{~Hz})$ (perbandingan frekuensi harmonic orde ganjil di mana $\left.f_{1}: f_{3}: f_{5}: f_{7}=1: 3: 5: 7\right)$. Saat frekuensi dipasang pada $120 \mathrm{~Hz}$ (nada dasar pertama), gelombang yang terbentuk berdasarkan pengamatan menunjukkan adanya perut tekanan pada ujung tertutup dan simpul tekanan pada ujung terbuka. Hal ini sesuai dengan teori pola gelombang yang terjadi pada pipa organa setengah tertutup, di mana pada ujung yang tertutup mempunyai tekanan yang lebih tinggi dari pada ujung terbuka. (Gambar 10)

Pada pola gelombang dalam resonator saat dipasang pada frekuensi $120 \mathrm{~Hz}$, terlihat 2 titik terakhir penurunan, yang secara teori pada titik-titik tersebut harusnya sinyal keluaran menunjukkan nilai yang tinggi.

Dalam hal ini ada beberapa hal yang dapat dibahas, yang pertama pada penutup karet yang dipasang di ujung resonator mengalami sedikit kebocoran sehingga tekanan yang terjadi sedikit berkurang tidak tertutup secara penuh. Hal kedua dimungkinkan karena mic yang digunakan mempunyai karakteristik dan batasan maksimum untuk pendeteksi bunyi, sehingga pada jarak titik tersebut kemampuan mic dalam mendeteksi bunyi sudah mulai berkurang.

Dari keempat frekuensi harmonik tersebut secara umum bentuk gelombang yang terjadi sesuai dengan 


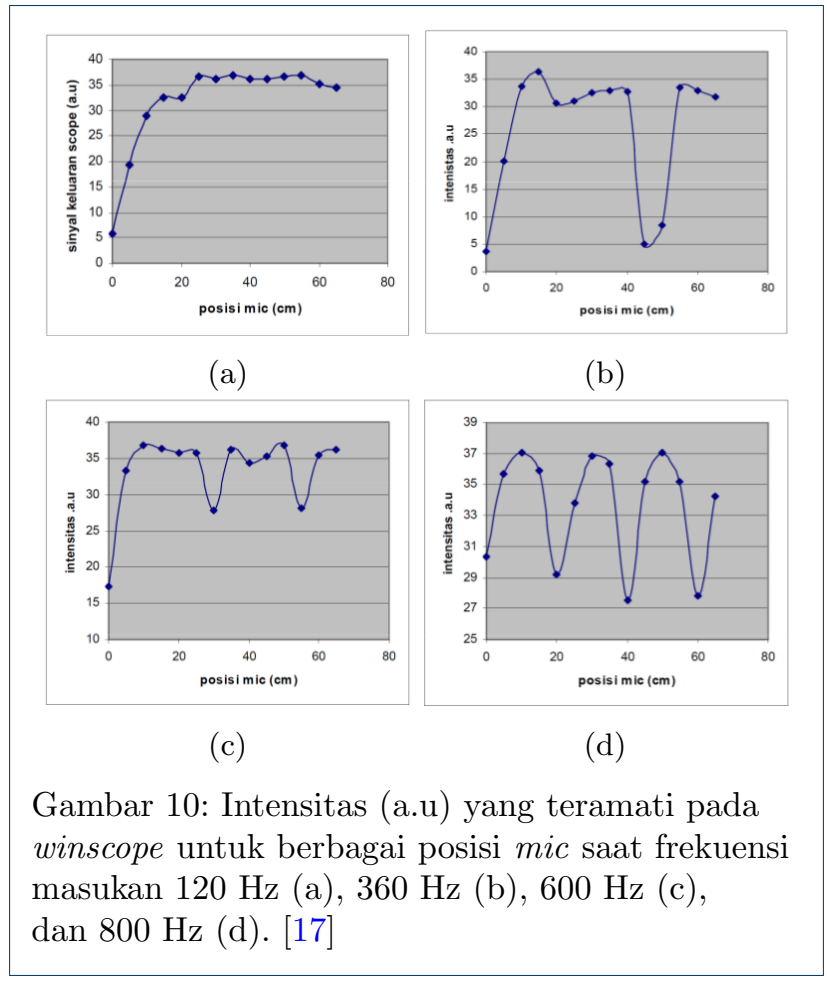

teori pola-pola gelombang pada resonator semi tertutup (Gambar 2). Untuk frekuensi yang lebih tinggi yaitu $360 \mathrm{~Hz}, 600 \mathrm{~Hz}$, dan $840 \mathrm{~Hz}$ pola gelombang yang terjadi mempunyai simpul dan perut simpangan lebih banyak. Hal ini merupakan bentuk konsekuensi dari suatu tabung pipa organa semi tertutup dengan panjang tetap dengan salah satu ujungnya terbuka dan ujung lainnya tertutup.

\section{Perbedaan suhu yang dihasilkan antara bagian panas dan dingin untuk berbagai posisi stack pada frekuensi harmonik orde pertama, ketiga, kelima dan ketujuh.}

Adapun perbandingan beda suhu maksimum yang dihasilkan dari kinerja pompa kalor termoakustik ketika beroperasi pada frekuensi harmonik orde ganjil (1, 3, 5 dan 7) dengan frekuensi harmonik orde pertama pada posisi stack pada $60 \mathrm{~cm}$ dari ujung terbuka menghasilkan beda suhu terbesar (Gambar 11). Perbedaan suhu yang dihasilkan antara tandon panas dan dingin setelah 10 menit pengoperasian adalah $27^{\circ} \mathrm{C}$, seperti terlihat pada Tabel 1 dengan kenaikan suhu sebesar $19^{\circ} \mathrm{C}$ dan penurunan suhu $7,6^{\circ}$ C.

Pada frekuensi harmonik pertama, beda suhu yang dihasilkan cenderung meningkat ketika posisi stack divariasikan mulai dari posisi $15 \mathrm{~cm}$ dari ujung sumber bunyi sampai posisi $60 \mathrm{~cm}$ dari ujung sumber

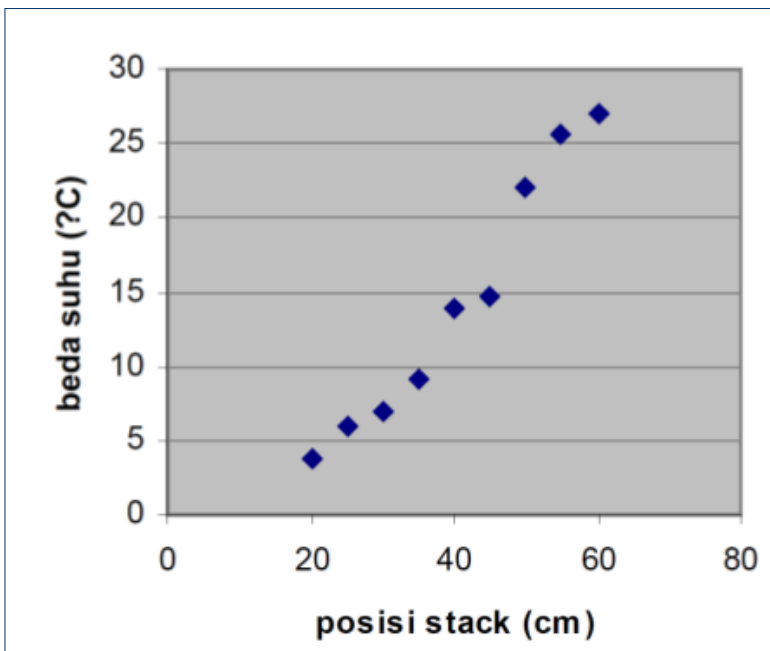

Gambar 11: rafik hubungan posisi stack $(\mathrm{cm})$ dan beda suhu $\left({ }^{\circ} \mathrm{C}\right)$ untuk frekuensi harmonik orde 1

Tabel 1: Perbandingan beda suhu maksimum yang dihasilkan untuk frekuensi harmonik orde 1, 3, 5, 7

\begin{tabular}{|c|c|c|c|}
\hline Orde Harmonik & $\Delta T\left({ }^{\circ} \mathrm{C}\right)$ & $T_{p}\left({ }^{\circ} \mathrm{C}\right)$ & $T_{d}\left({ }^{\circ} \mathrm{C}\right)$ \\
\hline 1 & 27 & 49 & 22,4 \\
\hline 3 & 9 & 38 & 29 \\
\hline 5 & 2,8 & 33 & 30,2 \\
\hline 7 & 1,2 & 32 & 30,8 \\
\hline
\end{tabular}

bunyi. Hal ini mempunyai kesesuaian dengan bentuk gelombang tekanan yang terjadi. Pada frekuensi harmonik ini sinyal keluaran yang teramati pada scope juga mengalami kecenderungan peningkatan dengan titik terendah berada pada ujung terbuka resonator.

Untuk frekuensi harmonik ketiga perbedaan suhu yang dihasilkan untuk tiap posisi stack juga menunjukkan adanya kesesuaian dengan bentuk gelombang yang teramati [17]. Beda suhu paling tinggi terdapat pada posisi $60 \mathrm{~cm}$ dari ujung terbuka atau $10 \mathrm{~cm}$ dari ujung tertutup (mendekati $\lambda / 20$ ). Hal ini dikarenakan pada posisi ini terjadi kesesuaian antara perbedaan tekanan dan kecepatan osilasi dari paket gas sehingga beda suhu yang dihasilkan maksimum [4].

Selain itu perbedaan posisi stack juga mengakibatkan perbedaan volume antara tandon panas dan dingin, sehingga hal ini juga berpengaruh pada beda suhu yang dihasilkan. Hal yang sama terjadi pada frekuensi harmonik orde kelima dan ketujuh, di mana beda suhu yang dihasilkan tiap variasi posisi stack mempunyai kesesuaian dengan bentuk gelombang yang terjadi.

Dari keempat frekuensi harmonik yang digunakan beda suhu terbaik yang dihasilkan terjadi pada frekuensi harmonik orde pertama yaitu $27^{\circ} \mathrm{C}$. Pada frekuensi harmonik pertama (frekuensi resonansi) 
akan menghasilkan beda suhu maksimal karena terdapat korelasi yang sesuai di mana proses transfer kalor terjadi dengan kecepatan osilasi yang sesuai. Apabila kecepatan osilasi dari gelombang bunyi lambat maka transfer kalor yang terjadi juga lambat sehingga beda suhu yang dihasilkan tidak optimal. Sedangkan pada saat gelombang bunyi berosilasi dengan cepat maka waktu untuk mengambil kalor saat berada di tandon dingin juga cepat sehingga kalor yang dipindahkan ke tandon panas hanya sedikit. Hal ini berakibat beda suhu yang dihasilkan pun tidak maksimal.

Dari keempat frekuensi harmonik, posisi stack terbaik yang dihasilkan semuanya sama yaitu pada posisi $60 \mathrm{~cm}$ dari ujung terbuka atau $10 \mathrm{~cm}$ dari ujung tertutup (mendekati posisi $\lambda / 20$ ). Sedangkan perbandingan beda suhu terbesar yang dihasilkan pada penelitian kali ini untuk frekuensi harmonik orde 1, 3, 5 dan 7 yaitu $(27: 9: 2.8: 1,2)^{\circ} \mathrm{C}$ (lihat Gambar 12) atau dengan pembulatan mempunyai perbandingan $27: 9: 3: 1$.

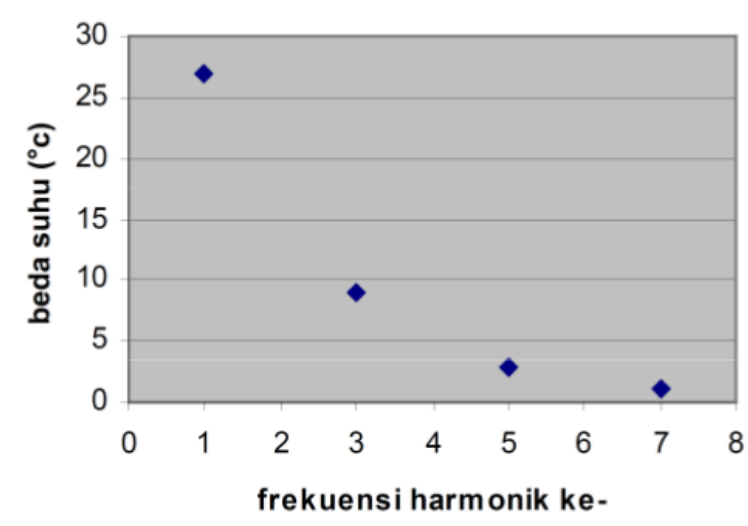

Gambar 12: Grafik frekuensi harmonik vs beda suhu optimum yang dihasilkan. [17]

Dapat dikatakan bahwa beda suhu yang dihasilkan mempunyai pola perbandingan 31 kali dari beda suhu yang dihasilkan oleh frekuensi harmonik sebelumnya. Beda suhu optimal pada frekuensi harmonik pertama, yaitu $27^{\circ} \mathrm{C}$ terjadi pada frekuensi $119 \mathrm{~Hz}$, adapun proses kenaikan dan penurunan suhu masing-masing tandon tertera pada Gambar 13.

Pada laju pemanasan dan pendinginan, satu hal yang perlu kita lihat adalah adanya aliran balik kalor yang menyebabkan suhu tandon dingin menjadi naik lagi karena pada daerah termampatkan volumenya kecil tetapi tekanan terus meningkat. Hal ini berakibat pada tumbukan yang terjadi antar molekul semakin besar sehingga terjadi aliran balik kalor dari tandon panas ke tandon dingin.

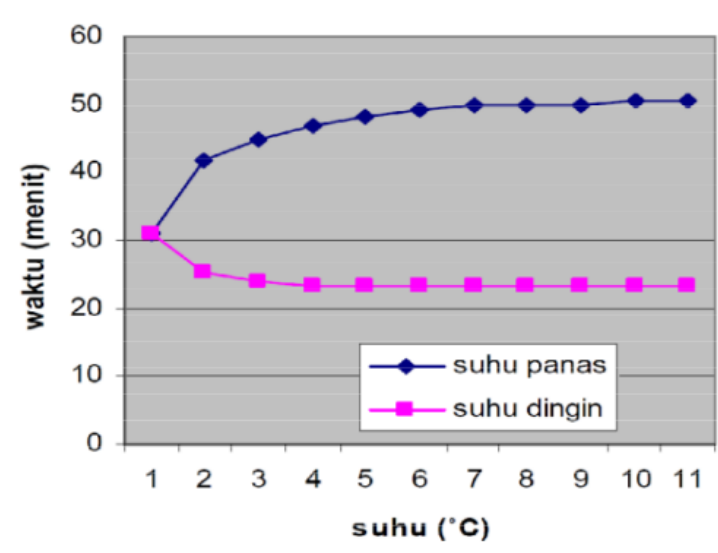

Gambar 13: Laju pemanasan dan pendinginan saat beroperasi pada frekuensi $119 \mathrm{hz}$ dengan stack pada posisi $60 \mathrm{~cm}$ dari ujung terbuka. [17]

Pada frekuensi resonansi meskipun input speaker dipasang maksimal $(\mathrm{V}=15$ volt), akan tetapi saat dioperasikan pada frekuensi harmonik ketiga beda suhu optimal yang dihasilkan $9^{\circ} \mathrm{C}$ pada posisi stack $60 \mathrm{~cm}$ dari ujung terbuka input speaker maksimumnya pada 13,5 volt. Sedangkan pada frekuensi harmonik kelima beda suhu optimum yang dihasilkan $2,8^{\circ} \mathrm{C}$ $(\mathrm{V}=11$ volt $)$, dan pada harmonik ketujuh beda suhu optimum yang dihasilkan $1,2^{\circ} \mathrm{C}$ untuk input speaker sama yaitu 11 volt dengan posisi stack pada $60 \mathrm{~cm}$ dari ujung terbuka. Perbedaan input speaker operasional maksimum ini diakibatkan karena frekuensi yang digunakan berbeda, di mana amplifier mempunyai karakteristik tersendiri untuk frekuensi tertentu.

\section{KESIMPULAN DAN SARAN}

\section{Kesimpulan}

Dari penelitian yang telah dilakukan, dapat disimpulkan bahwa :

Diameter pori-pori stack memengaruhi besar kecilnya nilai perbedaan suhu antara bagian panas dan bagian dingin dengan diameter pori-pori stack optimum didapat pada diameter $3,61 \mathrm{~mm}$ dengan perbedaan suhu $19^{\circ} \mathrm{C}$ antara bagian yang panas dan dingin. Sedangkan perbandingan beda suhu optimum yang dihasilkan saat beroperasi pada frekuensi harmonik orde 1, 3, 5 dan 7 adalah $27: 9: 3: 1\left({ }^{\circ} \mathrm{C}\right)$. Adapun posisi stack terbaik untuk frekuensi harmonik orde $1,3,5$ dan 7 sama yaitu pada posisi $60 \mathrm{~cm}$ dari ujung terbuka

\section{Saran}

Untuk mendapatkan hasil yang lebih akurat mengenai diameter optimum pori-pori stack, perlu dilakukan 
penelitian dengan variasi diameter pori yang lebih banyak. Di samping itu perlu dilakukan penelitian lebih lanjut dengan menggunakan stack diameter pori lingkaran untuk beberapa variasi panjang stack dan panjang tabung resonator. Hal lainnya adalah perlunya dibuat suatu perangkat peranti termoakustik yang mempunyai tingkat kebisingan rendah dengan menambahkan peredam bunyi yang lebih baik.

\section{Author}

1 Agus Cahyono

From :

(1) Jurusan Fisika, Fakultas Matematika dan Ilmu Pengetahuan Alam, Universitas Gadjah Mada

2 Wahyu Nur Achmadin

From :

(1) Jurusan Fisika, Fakultas Matematika dan Ilmu Pengetahuan Alam, Universitas Gadjah Mada

3 Ikhsan Setiawan

From :

(1) Jurusan Fisika, Fakultas Matematika dan Ilmu Pengetahuan Alam, Universitas Gadjah Mada

4 Agung Budi Setio Utomo

From :

(1) Jurusan Fisika, Fakultas Matematika dan Ilmu Pengetahuan Alam, Universitas Gadjah Mada

\section{Pustaka}

1. Wu F, Wu C, Guo F, Li Q, Chen L. Optimization of a thermoacoustik engine with a complex heat transfer exponent. Entropy. 2003;5(5):444-451

2. Anonim A. Thermoacoustics Heat Pump for Upgrading Industrial Waste Heat; 2007. Available from: http://www.ecn.nl/eei/ research/waste\{_\}heat/tahp/application.en.html.

3. Wheatley J, Hofler T, Swift GW, Migliori A. Understanding some simple phenomena in thermoacoustics with applications to acoustical heat engines. Am J Phys. 1985;53:147-162.

4. Swift GW. Thermoacoustic engine. In: Crocker MJ, editor. Encycl. Acoust. New York: Willey; 1997. p. 695-701.

5. Swift GW. Thermoacoustic engines and refrigerators. Phys Today. 1995;48:22-28.

6. Russell DA, Weibull P. Tabletop thermoacoustic refrigerator for demonstration. Am J Phys. 2002;70:1231-1233.

7. Swift GW. Thermoacoustic: A uniflying perspective for some engines and refrigerators. Los Alamos National Laboratory: Acoustical Society of America Publications; 2002.

8. Tijani MEH, Zeegars JCH, Waele TAM. The optimal stack spacing for Thermoacoustic Refrigerator. J Acoust Soc Am. 2002;112:128-130.

9. Biwa T, Yashiro Y, Kozuka M, Yazaki T, Mizutani U. Experimenta demonstration of thermoacoustic energy conversion in a resonator Phys Rev E. 2004;69(6).

10. Setiawan I, Utomo ABS, R W Andi. Laporan Penelitian antar Bidang Ilmu, Rancang Bangun Piranti Termoakustik Sebagai Pendingin dan Pemanas Udara Secara simultan. Yogyakarta: FMIPA UGM; 2005.
11. Setiawan I, Utomo ABS, Maruto G, Andi RW. Rancang Bangun Piranti Termoakustik Sebagai Pemompa Kalor. SIGMA J Sains dan Teknol. 2007;10(1).

12. Elyanita MS, Setiawan, Utomo ABS. Pengaruh Peubah Frekuensi dan Posisi Stack Bahan Kardus Terhadap Peubah Suhu pada Sistem Termoakustik. J Fis Indones. 2007;11.

13. Sampurna D, Setiawan I, Utomo ABS. Studi Eksperimen Untuk Mengetahui Pengaruh Diameter Tabung Resonator Silindris Terhadap Kinerja Piranti Termoakustik. J Fis Indones. 2007;11.

14. Wagiyanti. Kajian Pengaruh Panjang Stack Dan Panjang Alumunium Foil Pada Stack Terhadap Perbedaan Suhu Pada Kinerja Pompa Kalor Termoakustik [Skripsi]. UGM; 2006.

15. Tipler PA. Fisika untuk Sains dan Teknik. 3rd ed. Jakarta: Erlangga; 1998.

16. Cahyono A, Setiawan I, Utomo ABS. Analisis Variasi Diameter Stack Berpori Lingkaran. Berk IIm MIPA. 2013;23(1).

17. Cahyono A. Analisa Perbandingan Kinerja Pompa Kalor Termoakustik pada Frekuensi Harmonik orde 1, 3, 5, dan 7 untuk stack Berpori Lingkaran [Skripsi]. Universitas Gadjah Mada; 2007 